\title{
LEADERSHIP CONCEPT AT SHARIA BANK; A THEORETICAL STUDY
}

\author{
Havis Aravik \\ Sekolah Tinggi Ekonomi dan Bisnis Syariah (STEBIS) Indo Global Mandiri Palembang \\ Email: havis@stebisigm.ac.id \\ Dwi Sulastyawati \\ IAIN Curup, Bengkulu \\ Email: dwisulastyawati@iaincurup.ac.id \\ Nur Rohim Yunus \\ Kazan Federal University (KFU), Kazan, Tatarstan Rusia \\ Email: nurrohimyunus@yandex.ru
}

\begin{abstract}
The issue of leadership has always been an important and interesting theme to be discussed since it is one of the influencing factors of the success or failure of an organization. Therefore, this article seeks to discuss the sharia bank leadership concept through a theoretical study to provide a clear picture of the leadership concept in sharia banks in theory. This study used library research because all data processed were the library data analyzed with a qualitativedescriptive analysis. The results of this study show that the leadership concept of sharia banks ideally models on the leadership of the Rasulullah (Messenger of Allah) SAW, starting from being smart in communication to being an agent of change, as a coach with the dedication vision and the charismatic spirit.
\end{abstract}

Keywords: Leadership, Leader, Islamic Bank, Rasulullah SAW

\section{Introduction}

The issue of leadership is the most interesting and never-ending discussion as it is one important factor that influences the success or failure of an organization. It must be admitted that an organization will be able to achieve its objectives when it has a sufficient source of capital, and accurate organizational structure, and a skilled workforce. Although these factors are closely related to the success or failure of the organization, leadership is also an important factor that needs to be considered. Without good leaders, the wheels of the organization will not run smoothly (Aravik \& Zamzam, 2019). 


\section{2}

Havis Aravik, Dwi Sulastyawati, Nur Rohim Yunus, LEADERSHIP CONCEPT AT SHARIA BANK...

Leadership is a process of influencing, inspiring and being a top figure for the community that will be or is being led. Therefore, the leader is a person who determines the final work and, at the same time, monitors the concrete work of the "subordinates" in the field. The work quality of the subordinates depends on how strong the influence of management is applied by a leader. Meanwhile, in the normative level, the leader must be able to "condition" his subordinates stably. This is certainly not an easy task. However, when someone has been involved in the organizational structure in the sense of being a leader, the logical consequences is he must be able to do it.

A leader in the Islamic manhaj is very final and fundamental. He occupies the highest position in the building of Islamic society. The ability to lead directs his people to the goals to be achieved, namely the glory and welfare of the people with the blessing of Allah SWT. Imamah or Islamic leadership is a concept contained in the Al-Qur'an and As-Sunnah, which includes human life from individuals, a couple, families, and even humanity or groups, as well as human interaction with others, nature and God. This concept encompasses both ways of leading and being led for the implementation of Islamic teachings that guarantee a better life in the world and the hereafter.

From the above problems, the study of leadership is very appropriate when it is contextualized to sharia banks as one of the financial instruments based on religious values (sharia) oriented to both profits and benefits for many people (Aji, 2012), so it can be a standard reference in managing the sharia banking system in the future because the progress and failure of sharia banks is largely determined by the skipper behind the wheel, that is, the leader who regulates, manages and implements visionary ideas to produce progress for sharia banks and, of course, impact on the welfare of the employees, customers and the Islamic community in general.

\section{Basic Concept of Leadership}

Etymologically, leadership means the power to make a move and influence people. Leadership is often interpreted as the ability to influence others to achieve better conditions. It is implemented not for self-interest but for the interests of achieving organizational goals. Leadership is an inevitable element in life. It is human nature to 
always form a community and in a community, a leader is always needed. A leader is a person who is used as a reference when the community faces various life problems. He is a person who provides visions and goals. In a group, let's say in an organization if it has no purpose, it is tantamount to disperse the organization. This also applies to every organization, including in the scope of the state level (Harahap, 2016).

According to Veithzal Rivai (2013), essentially, leadership means: first, the process of influencing and setting an example by a leader to his followers to achieve organizational goals; second, arts influence and direct people by obedience, trust, respect and cooperation that is passionate about achieving common goals; third, the ability to influence, inspire and direct the actions of a person or group to achieve the expected goals; fourth, it involves three things, namely leaders, followers and certain situations; and fifth, the ability to influence a group to achieve its goals. The source of influence can be formal or informal. Formal influence is interpreted when a leader has a managerial position in an organization, while sources of informal influence emerge from outside the formal organizational structure. Thus, a leader can emerge to be born from the organization or formally appointed.

Hughes, et al. (2002) assert that leadership is not a particular position, but rather a complex process that involves interaction between leaders, the external environment, and subordinates. Based on this view, leadership is defined as the process of influencing organized groups that leads to the achievement of organizational goals. The existence of a leader plays an important role in an organization. The role of a leader is as a direction and goal in the future (direct setter), a change agent, a negotiator (spokes person), and a coach.

Leadership is an effort of a leader to be able to realize the organizational goals through others by motivating so that they are willing to carry it out. Therefore, the balance between the individual needs of the implementers and the company's goals is needed. The scope of leadership is not only to internal organizational problems but also to external problems (Harahap, 2016). 


\section{4 | Havis Aravik, Dwi Sulastyawati, Nur Rohim Yunus, LEADERSHIP CONCEPT AT SHARIA BANK...}

\section{Leadership in Islam}

Leadership in Islam is known as Imamah. Islamic leadership is a concept contained in the Al-Qur'an and As-Sunnah, which includes human life from individuals, a couple, families and even to humanity or groups. This concept encompasses both ways of leading and being led for the implementation of Islamic teachings to guarantee a better life in the world and the hereafter as its goal (Harahap, 2016). Leadership is nature stated clearly in the Al-Qur'an where humans are entrusted by Allah to become Hia caliph (Allah's representative) on earth (QS. Al-Baqarah [2]: 30). The task of the caliph is to realize welfare and prosperity in life including building, managing, and maintaining the earth as an effort to support the smooth task of worship to Allah SWT (QS. [11]: 61) (Aravik and Zamzam, 2020).

In addition to Imamah, in Islam, leaders are often referred to the terms such as Umara and Ulil Amri which means the leader of the state or government, Amirul Mu'minin which means the leader of ummah, Al-Qiyadah which means a group leader, Al-Mas-uliyah which means the person in charge, and Khadimul Ummah which means the servant of ummah. The leader becomes one of the important pillars to revive Muslims who are known to have the most orderly and perfect manhajul hayat (the concept of life) compared to concepts created and imagined by the human brain. The existence of leadership has a syar'i and 'aqli foundation as reflected in QS Al-Fur'an [25]: 74, and An-Nisa' [4]: 59.

Nawawi (2011) states that leadership in Islam is divided into two notions, spiritually Islamic and empirical. In the Islamic spiritual perspective, Islamic leadership is interpreted as the ability to carry out commands and not do the prohibitions of Allah SWT, both collectively and individually. In other words, leadership is the ability to realize all the will of Allah SWT, which He has told through His Messenger, Muhammad Peace be upon him. Meanwhile, empirically, Islamic leadership is an activity carried out by humans in the life of society as an effort to realize togetherness (sociality).

Leadership is an unavoidable social fact to regulate relations between individuals who are members of a society, where each individual has a collective goal to be realized 
together in society. Leadership is a universal phenomenon that exists in every group of people as a social system, ranging from a small group of some people to a large group, called nations. The symptoms of leadership have been widely studied by experts so that there are enough theories available as an analytical tool to discuss.

\section{Sharia Bank Leadership}

Leadership is the power to influence someone to do or not to do something. Thus, leadership requires the active use of abilities to influence others and to realize the stated organizational goals. In a structural context, leadership is defined as a process of motivating so that people who are led to carry out activities or work by a predetermined program. Leadership also means efforts to direct, guide and influence others, so that their thoughts and activities do not deviate from their respective main tasks. As for the non-structural context, leadership can be interpreted as a process of influencing thoughts, feelings, behaviours, and mobilizing all facilities to achieve the goals set together (Nurhayati, 2012).

In the sharia bank aspect, leadership is one of the important factors in running the organization's wheels. A leader is the first to determine the direction of the sharia bank to realize its targets. Therefore, when referring to the guidance of the Rasulullah SAW as the best man in the world, his words are always in the guidance of the revelations of Allah SWT An-Najm [53]: 3-4) and his attitude to life is a reflection of the Al-Qur'an (QS. Al-Qalam [68]: 4) (Aravik, 2016). Then, the leadership characteristics that must apply to sharia banks are as follows:

\section{Smart in communication.}

The ability to communicate in Islam is the same as silaturahmi (getting together). With frequent communication, there will be a lot of communication. Smart, good, honest, and interesting communication will greatly help a leader in building relationships with the people they lead (Zamzam \& Aravik, 2016). Good communication can provide understanding and calmness for the listener. This principle 


\section{Havis Aravik, Dwi Sulastyawati, Nur Rohim Yunus, LEADERSHIP CONCEPT AT SHARIA BANK...}

must be able to be done by a leader in implementing his leadership, including in sharia banks.

Some methods of communication exemplified by Rasulullah SAW that must be had by every sharia bank leader are a). Qaulan Kariimah (must be with noble words). In this context, a sharia bank leader must not insult, vilify, make fun of, and hurt others (QS. Al-Isra' [17]: 23). b). Qaulan Ma'rufan (must be with good words). This means that a sharia bank leader will not speak in vain and not use words that cause mudharat (QS. An-Nisa [4]: An-Nisa [4]: 8, Al-Baqarah [2]: 263). c). Qaulan Sadidan (must be with the straightforward and right words). This means that a sharia bank leader must always be in the corridor of truth, not lying, not cheating, and not manipulating facts for his interests (QS. Al-Ahzab [33]: 70-71). d). Qaulan Balighan (must be with the right words). This means that a leader of a sharia bank must communicate with words that are effective, right on target, easy to understand and to the point of the issue. A leader must not confuse his subordinates in translating what he conveys (QS. An-Nisa' [4]: 63). e). Qaulan Maysura (must be with words that are easy to understand). This means that in communication, a leader must be able to convey information that is easily digested and understood by the people they lead (QS. Al-Isra' [17]: 28). f). Qaulan Layyinan (must be with gentle words). A sharia bank leader must be able to say gently and soothingly. He must not shout, especially when giving directions and advice to his subordinates (QS). Thoha [20]: 44) (Zamzam and Aravik, 2016).

This ability to communicate is reflected in the understanding of the vision and mission of sharia banks which consist of the commitment to operate under sharia principles, providing returns by sharia, serving the needs of all Muslims, committing to only being involved in investments permitted by Islamic teachings, including understanding in governance of sharia banks which refers to the principles of transparency, accountability, responsibility, professionalism, and fairness.

\section{Change agent}

A leader is an agent of social change in society, including in sharia banks. Gibson, Ivancevich and Donnelly revealed that a leader must be able to be an example and role 
model for anyone he leads, which is reflected by his behaviour, attitudes, performance and ability to work (Jannah, Suwardi, Iriyanto, 2016). Then, the sharia bank leaders must be able to strive for all leadership activities for the achievement of benefit for humans and to protect themselves and their communities from various interpretations (damage). A sharia bank leader must make the right rule of game and rule of law that can make sharia banks become the main reference for people to invest their money, not just the same as conventional banks, only different in labelling sharia. As a change agent, sharia bank leaders must become visioners in providing excellent services to customers and the public and in introducing new products, investment activities, intense communication and collaboration with the Sharia Supervisory Board (DPS) and others.

\section{Coach}

A sharia bank leader is a driving force for all banking activities in achieving the objectives set. For this reason, his main task is to provide good examples and role models for his subordinates in carrying out their duties (QS. Al-Shaff [61]: 2-3, AlAhzab [33]: 21, Al-Qalam [68]: 4). He must be able to work hard to play its function to become yatafaqqohu fiddin (disseminating knowledge and understanding to subordinates and customers) and yunziro qoumahum (giving direction to customers and subordinates to understand and comprehend the commands given). Furthermore, as a coach, a sharia bank leader must be able to guide and show the way of happiness to his subordinates under the guidance of Allah SWT (QS. Al-Anbiya '[21]: 73) by colouring one's life with virtue and making it in the culture of his life (QS. al-Anbiya' [21]: 7, and Al-Nahl [16] 125). Besides, as a coach, a sharia bank leader must be able to implement sharia bank governance in compliance with the principles stipulated in the sharia banking law, namely business activities that do not contain elements of riba, maysir, gharar, haram and zalim (Abubakar and Handayani, 2017).

\section{Having a Vision in Service}

A sharia bank leader must be able to become a visionary role model. Service is his way of life in carrying out the mandate in leadership. Thus, in carrying out this duty, the 


\section{Havis Aravik, Dwi Sulastyawati, Nur Rohim Yunus, LEADERSHIP CONCEPT AT SHARIA BANK...}

sharia bank leader must be patient (QS. Sajadah [32]: 24), prioritizing the interests of customers and subordinates above the interests of everything, and willing to cooperate with others consistently. He must be able to resolve problems with consensus agreement to get an ideal solution, as is the practice in the leadership of Rasulullah and Khulafaur Rasyidin (Zamzam \& Aravik, 2016).

This vision of service is reflected in commitments to employees such as appreciation in the form of rewards, equal opportunity policies, giving workshops or sharia pieces of training, and so forth. To the customers and the community, it can be seen from the ability of sharia banks to create new employments, take side to women, children and people with special needs, provide corporate social responsibility funds through zakat, infaq and sadaqah or in the form of sponsoring community activities, and being involved in organizing economic conferences and sharia banking.

\section{Having a Charismatic Spirit}

Charismatic according to Yukl (2010) is a great strength of a leader to motivate his subordinates in carrying out the tasks. Others state that charismatic is the ideal influence of individual qualities that make him different from others and can be trusted (Robbins, 2015). Setiawan (2013) mentions that a leader who has an ideal influence can be seen from giving in realizing vision and mission to his followers, having respect and trust. Like Setiawan, Cemaloglu (2012) says that the ideal influence means giving vision and mission to the followers and undergoing the process. Lai (2011) says the ideal influence gives a positive response to statements, such as; 1 ). The leader feels proud of the people he works with. 2). The followers know the importance of a vision and mission

As well as sharia bank leadership. A leader must have more charisma and energy, in addition to extraordinary attractiveness and character to influence others, so that everyone is willing to be a follower without coercion. Charismatic spirit will not emerge if a leader does not have the al-muktasab and mustafad mind that can produce the virtues of Allah SWT and pay attention to everything that develops in the empirical world along with everything that results (mura'at ma fi al- kharij wa ma yalhaquha min al-ahwal wa yatba'uha). Because leadership is about relationships where a person, a 
leader, influences the other party to work together voluntarily in trying or doing related tasks, without a charismatic spirit, it is difficult to achieve what the leader wants (Sudaryono, 2017).

These five characteristics of sharia bank leaders are very important not only because the progress of sharia banking life depends on the ability of a leader to control his people, equipment, resources, and other sources, but also because the welfare which becomes the ideal goals of Islamic banking more or less lies in the shoulders of its leader. Moreover, one of the main obstacles in the growth of the sharia finance industry, especially sharia banking, is the lack of transparency and good governance. This lack of transparency and governance is seen in several strategic issues including products that are not varied and services that are not in line with community expectations, inadequate quantity and quality of human resources, understanding and awareness of the community that is so low that it raises community misperceptions related to terms, contracts and products, the view that sharia banking is expensive, and the regulation and supervision that are not yet optimal (Abubakar \& Handayani, 2017). All of these can be anticipated and minimized by the ability of a leader in controlling, directing, and organizing all components related to sharia banks.

The good side of the development of sharia banks in Indonesia is it has now become a benchmark for the success of sharia economic existence. Sharia banking can use this moment to show that sharia banking is truly capable of competing and becoming the lighthouse for the existence of sharia-based national banking (Ichsan, 2012). Of course, one of the supporting factors that play an important role in this problem is leadership. The driver behind the sharia banks will determine the development of sharia banks in the future.

\section{Conclusion}

Condidering the explanation above and the issues discussed, we can conclude that leadership is a vital element in an organization. The progress and retreat of the organization's wheels are largely determined by the leader behind it, including in sharia banks. Sharia banks are banking institutions that are run with sharia values. Thus, in 


\section{0 | Havis Aravik, Dwi Sulastyawati, Nur Rohim Yunus, LEADERSHIP CONCEPT AT SHARIA BANK...}

carrying out the leadership, it must be under divine values. There are at least five characters that must be possessed, among others, smart in communication (qaulan kariimah, qaulan ma'rufan, qaulan sadidan, qaulan balighan, qaulan maysura, and qaulan layyinan), becoming a change agent for subordinates and customers, becoming a supervisor especially in yatafaqqohu fiddin and yunziro qoumahum, having a vision of service in carrying out the mandate, and having a charismatic spirit. These characters are expected to be able to oversee sharia banks to be equal and become the main reference for community banking, especially in Islam.

\section{Reference}

Abubakar, Lastuti and Tri Handayani, (2017). "Percepatan Pertumbuhan Perbankan Syariah Melalui Implementasi Tata Kelola Syariah", Jurnal Law and Justice, Vol. 2, No. October 2, 2017. DOI: https://doi.org/10.23917/laj.v2i2.3417.

Aji, A.M. (2012). Urgensi Maslahat Mursalah Dalam Dialektika Pemikiran Hukum Islam, Bogor: Pustaka Pena Ilahi.

Aji, A.M. (2015) "Hak dan Kewajiban Asasi Manusia Dalam Perspektif Islam," Salam; Sosial dan Budaya Syar-i, Volume 2, No. 2.

Aravik, Havis, Fakhry Zamzam (2020). Filsafat Ekonomi Islam; Ikhtiar Memahami Nilai Esensial Ekonomi Islam, Jakarta: Kencana.

Aravik, Havis (2017). Sejarah Pemikiran Ekonomi Islam Kontemporer, Jakarta: Kencana.

Harahap, Sunarji, (2016). "Pengaruh Kepemimpinan Islami dan Motivasi Kerja Terhadap Kinerja Karyawan Pada PT. Bank Syariah Mandiri, Tbk Kantor Cabang Pembantu Sukaramai Medan", Human Falah, Volume 3. No. July December 2, 2016.

Hughes, R.L., Ginnett, R.C., \& Curphy G.J. (2002) Leadership: Enhancing The Lesson of Experience. New Jersey: Prentice-Hall

Ichsan, Nurul, (2012). "Perkembangan Perbankan Syariah Dalam Menghadapi Tantangan Zaman", Jurnal Ekonomi Islam, Volume 2, Nomor 2, September 2012.

Jannah, Miftachul, Suwardi, Setia Iriyanto, (2016). "Analisis Kepemimpinan Islam Terhadap Kinerja Karyawan (Studi Kasus Pada PT. Bank Mumalat Indonesia Tbk, Cabang Semarang)", Value Added; Majalah Ekonomi dan Bisnis, Vol. 12, No. 1 (2016).

Nawawi, Hadari, (2011). Manajemen Sumber Daya Manusia, Yogyakarta: Gadjah. Mada University Press. 
ISLAMIC BANKING Volume 5 Nomor 2 Edisi Februari 2020 | 31

Rivai, Veithzal. (2013) Manajemen Sumber Daya Manusia untuk Perusahaan. Jakarta: Rajawali Pers.

Robbins, S. P., (2015). Organizational Behavior (16th ed.) London: Pearson Education.

Setiawan, D., (2013). Pengaruh Gaya Kepemimpinan Transformasional dan Transaksional Terhadap Kepuasan Kerja dan Kinerja karyawan di PT Tohitindo Multi Craft Industries Krian. Jurnal Universitas Katolik Widya Mandala Surabaya, Vol.2 No.1. Surabaya.

Sudaryono, (2017). Pengantar Manajemen; Teori dan Kasus, Yogyakarta: CAPS; Center for Academic Publishing Service.

Yukl, A. G., (2010). Leadership In Organizations. (7th ed.) New Jersey, Prentice-Hall.

Zamzam, Fakhry, Havis Aravik, (2016). Manajemen SDM Berbasis Syariah, Bogor: CV. RWTC Success. 
32 | Havis Aravik, Dwi Sulastyawati, Nur Rohim Yunus, LEADERSHIP CONCEPT AT SHARIA BANK... 